\title{
From Classroom to Career Development Planning: ePortfolio Use Examples
}

\author{
http://dx.doi.org/10.3991/ijet.v9i6.4027 \\ A. Coric Samardzija, I. Balaban \\ University of Zagreb, Varazdin, Croatia
}

\begin{abstract}
In this paper we will present several examples of different maturity levels of ePortfolio usage at the Faculty of Organization and Informatics, University of Zagreb, Croatia. Firstly, we will illustrate basic in-class uses of ePortfolio in which students are introduced with the ePortfolio concept, self-reflection, self-monitoring and knowledge management. The primary goal of this phase is to show students how to record, plan and improve their professional skills in order to facilitate their preparation for the labour market. This phase is also aimed at recording and showcasing of students' work and self-assessment. The second example of ePortfolio usage in this paper concerns self-guidance monitoring at the postgraduate level, where it is used to monitor the activities and progress of $\mathrm{PhD}$ students as well as to simplify communication between supervisors and doctoral candidates. In addition, by using the ePortfolio pattern, doctoral students are encouraged to start planning their careers as scientific researchers and experts. Finally, we introduce an example of using ePortfolios for academic human resources management as part of institutional quality assurance. For that purpose, a career development plan was developed to collect and monitor the work and progress of academic staff (both young researchers and teaching assistants).
\end{abstract}

Index Terms-ePortfolio, self-reflection, self-monitoring, career development plan.

\section{INTRODUCTION}

In our time there is an increasing tendency to digitization in everyday life, which also involves personal documents such as birth certificates, education certificates, marriage certificates and work experience records, among others. This trend can be explained by a simple fact that digital data is easier to access and manipulate, and its transmission is faster and less costly. Digitization has been adopted in formal, non-formal and informal education as well as a way to respond to the need of different stakeholders (teachers, supervisors, employers and others) to have easy and fast access to the information about learners' knowledge background, skills, competences and progress. ePortfolio is one of the concepts that has enabled 'digital communication' among learners as well as between learners and other stakeholders. Owing to its flexibility and adaptability to different contexts, ePortfolio has brought about a profound change in the traditional educational system.

By presenting our experiences using ePortfolio for several different purposes at the Faculty of Organization and Informatics, University of Zagreb, Croatia, we intend to help other institutions in similar undertakings. First we will show some examples of in-class ePortfolio usage, in which students are taught to use this tool for recording, self-reflection and knowledge management. Although these activities are primarily conducted at the undergraduate level of study at the Faculty of Organization and Informatics, ePortfolio is also used in some graduate courses. In the second example we will present ePortfolio used at the doctoral study level to monitor PhD students, their work, plans and progress as well as to help supervisors to communicate with candidates. This particular case of ePortfolio use is aimed at encouraging doctoral students in balanced planning of their career as scientific researchers and experts. In our case, to help $\mathrm{PhD}$ students to better manage their ePortfolio, a guide for doctoral portfolio structure was also developed. The doctoral portfolio was also used by $\mathrm{PhD}$ students for self-presentation, not only to their teachers, supervisors and mentor(s), but also to other stakeholders such as potential employers, project managers and colleagues. Finally, we will provide an example of using ePortfolio to monitor the work of young researchers and teaching assistants as well as to enable supervisors to gain insight into the work of their subordinates as part of the Faculty's quality management plan. In that respect, we will present elements for monitoring that also enable young employees to develop their CDP (Career Development Plan), thus enabling the Faculty to recognize skills of its employees and manage them accordingly, as a prerequisite of human resources management. Increasing requirements for academic employment make career management even more vital in improving one's chances for future employability.

\section{BACKGROUND}

The current economic crisis has revealed many shortcomings of the educational process. Upon successful completion of their studies, a lot of young people are facing difficulty finding a job. In many cases, the knowledge gained in the course of study does not make graduates competitive enough to ensure them to participate successfully in the labour market. The lifelong learning concept has recently been advanced to fill this gap. Although most people conceive of online learning as a purely academic endeavor, it should also be taken into consideration that "the need to learn and grow is equally important in the world of business and academia" [1]. Lifelong learning is usually defined as purposeful ongoing learning activity, with the aim of improving knowledge, skills and competence [2]. It offers the possibility to stay involved in the learning process that meets learners' needs. This concept encompasses three types of learning: formal, non-formal and informal learning. Formal learning is performed within an organized and structured context and usually ends with some kind of paper certificate as proof of learning 
success. By contrast, the non-formal type of learning takes place in a formal environment but is not formally recognised within the educational system curricula. It typically includes workshops, courses or conference style seminars that are offered by educational or social agencies. Informal learning is the one that occurs through everyday activities in a variety of places (home, work etc.) and daily interactions with members of society.

The approaches to teaching have evolved over time from the behavioural approach, through the cognitive approach and to the constructivist approach [3]. Changes introduced by constructivism include learner-centered approach, learning by doing, students' active participation and encouragement of their critical consideration of the content. On the other hand, technological developments have provided numerous benefits for education such as open source systems and tools, 24/7 accessibility, interoperability, to name just a few. As a result, a growing number of educators are actively trying to support the teaching process with the new ICT in order to make it more effective and learner-focused. ePortfolio is a relatively new phenomenon that has gained huge popularity over the last few years. ePortfolios are an extension of the traditional paper-based portfolio concept and are usually defined as a purposeful collection of information and digital artifacts that demonstrates the development (and evidence) of learning outcomes, skills, or competencies [4]. They are a highly flexible technology that can be applied to different learning contexts at different learning stages. They have a great potential to support both the cognitive and constructivist learning approach. In using ePortfolio, the emphasis is on the learning process rather than on its result [5]. From the teachers' point of view ePortfolio enables better assessment and provides a bigger picture of students' work over time [6].

In the course of its development, ePortfolio implementation has seen various transformations. Taking into account different uses of ePortfolio including assessment, employment, learning and teaching, it has to be noted that basically their concrete application ultimately depends on the purpose for which they are aimed [7]. Among the earliest and most common applications of the ePortfolio system is using it as a collection of created artifacts and reflections that represent outcomes of the learning process (Figure 1). Such collections of learners' work are further used as the basis for the assessment of learners' progress. However, ePortfolios differ from learning management systems in their ability to offer a personalized learning environment and support social networking, which locates them within Web 2.0 technologies [8]. In comparison with paper-based portfolios, ePortfolios have the potential to facilitate greater interaction between learners and teachers as well as among learners. Some studies suggested that ePortfolio use significantly facilitates the performance of knowledge management regarding the following aspects: knowledge sharing, innovation, acquisition, application, and accumulation [9]. Furthermore, ePortfolios were recognized as an environment where students can make their own learning experience [10]. It was reported that the most important factor that affects behavioral intention and attitudes towards using ePortfolios is user motivation [11]. Moreover, the broadened social context has effects on learner progress as well.

ePortfolio practitioners realized that ePortfolio has potential beyond that of a collection of created artifacts and

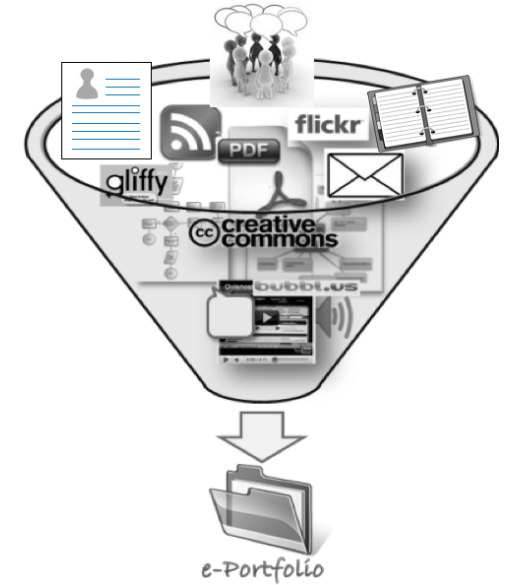

Figure 1. The concept of an electronic portfolio (ePortfolio) system

can be used as a showcase of learners' achievements, skills, experiences and competencies (Coric et al., 2011; Balaban et al. 2010). Dalton (2007) recommended that launching an ePortfolio system in the educational environment should primarily focus on preparing and presenting students for career-advancement opportunities. This can be explained by the fact that most college students are still uncertain about their career choices and using an ePortfolio system for this purpose can help students to successfully make transition from learning to post-college development [12]. Features contained within ePortfolio systems enable learners to define their future goals (career orientation, skills development etc.) and along with that plan and manage their short- and long-term plans. From the pedagogical point of view ePortfolios can facilitate the development of learners' self-awareness of their values, knowledge, strengths, weaknesses, goals and interests. In other words, it enables learners to better manage their personal growth and development. The creation of ePortfolios usually takes time and skill regarding the organization of its various elements, especially when they need to be used for a specific purpose, which can result in frustration [10]. Therefore, before starting to use ePortfolios, it is essential to provide users with a thorough introductory seminar/workshop on using ePortfolio accompanied by written instructions.

\section{EXAMPLES OF EPORTFOLIO USE}

\section{A. Learning management at undergraduate and graduate level}

In this section we will present some examples of ePortfolio use by undergraduate and graduate students in several courses at the Faculty of Organization and Informatics, University of Zagreb in which the Mahara Open Source system was implemented. In general, the main reasons for introducing ePortfolio were to encourage students to document and monitor their learning and integrate the artifacts they had created through different course activities (seminar papers, projects etc.) in order to organize all the results of their work and make it available at a single online location. These types of online evidence for student activities allowed teachers to assess and to measure whether the learning outcomes had been achieved in accordance with the curriculum. Among the activities that we successfully implemented in our courses: (1) developing a showcase portfolio; (2) keeping a learning diary. 
The goal of the showcase portfolio was to motivate students to start managing their private, academic and professional career as early as possible. Considering the harsh competition in the labour market in Croatia, students future job candidates - need constant skills improvement to be able to respond to the market demands, especially in field of ICT. Using ePortfolio as a showcase can enable them to better understand themselves and to define their personal and professional goals that they want to achieve through their studies. The fact that students were able to see other students' profile and were aware that other students were able to see theirs as well encouraged them to put a little more effort in composing and improving the content of their profile page. An example of a student's ePortfolio showcase is shown in figure 2 (in Croatian: cover letter, personal skills, professional skills, professional goals, personal goals, interests etc.).

From our experience several benefits of using ePortfolio as a showcase are: enhanced students' self-understanding (of their goals, skills, interests) and possibility to create online evidence of their education history and skills gained through the learning process. The ePortfolio system also enabled students to decide on the content access rights that can be assigned not only to teachers and peers but also to other persons outside the system such as parents or future employers.

Learning diary, in which students had to record their activities in specific a course, is another application of ePortfolio at the undergraduate and graduate study level. The diary provided students with online learning space to document and reflect upon course content of each lecture. In particular, they made online collections of notes and shared them with others (if it was necessary). They also made a rich multimedia collection comprising thoughts, pictures, video and audio files, with the possibility to integrate various artifacts that represented outcomes of their learning process (i.e. presentations, seminars and other artifacts created using Web 2.0 tools for creating mind maps, block diagrams, podcasts etc.). In addition, students organized and personalized their online learning environment in accordance with their preferences. The diary was principally aimed at stimulating students' creativity, reflective and critical thinking, and facilitating collaborative and peer to peer learning.

At the Faculty of Organization and Informatics students are enrolled in an average of seven courses per semester, which entails a fair amount of student workload. Introducing the learning diary was therefore intended for students to record their findings, observations, and insights in an online space as soon as possible to prevent forgetting. We also encouraged students to continue this practice in other courses. An example of a student's ePortfolio learning diary (in Croatian: theoretical lecture summary, practical part and integrated artifacts) is shown in figure 3.

Presented activities in the ePortfolio extended the learning time of students beyond that limited to tuition hours. However, although this activity demanded more engagement from students, it eventually resulted in having to allocate less time to revise for exams. In spite of additional time and commitment, a positive impact on motivation and success in mastering the course content was achieved by the learning diary. Another beneficial outcome of ePortfolio use proved to be increased interaction between teachers and students, where teachers acted as facilitators and supported students' work, helping them to overcome obstacles that would arise.

Among the negative aspects of ePortfolio use it was noted that sometimes teachers get more concerned with technical aspects and design of learners'portfolios than the quality of the artifacts and their critical reflection about course content. To avoid that, assessment rubrics can be used to increase the transparency, objectivity and fairness in grading students' work. Some of the criteria included in the assessment rubrics which were applied in our learning diaries are quality of summarization of key content, quality of students' observations and reflections about content, quality and accuracy of created artifacts, originality of thinking, organization and presentation of information as well as grammar and punctuation.

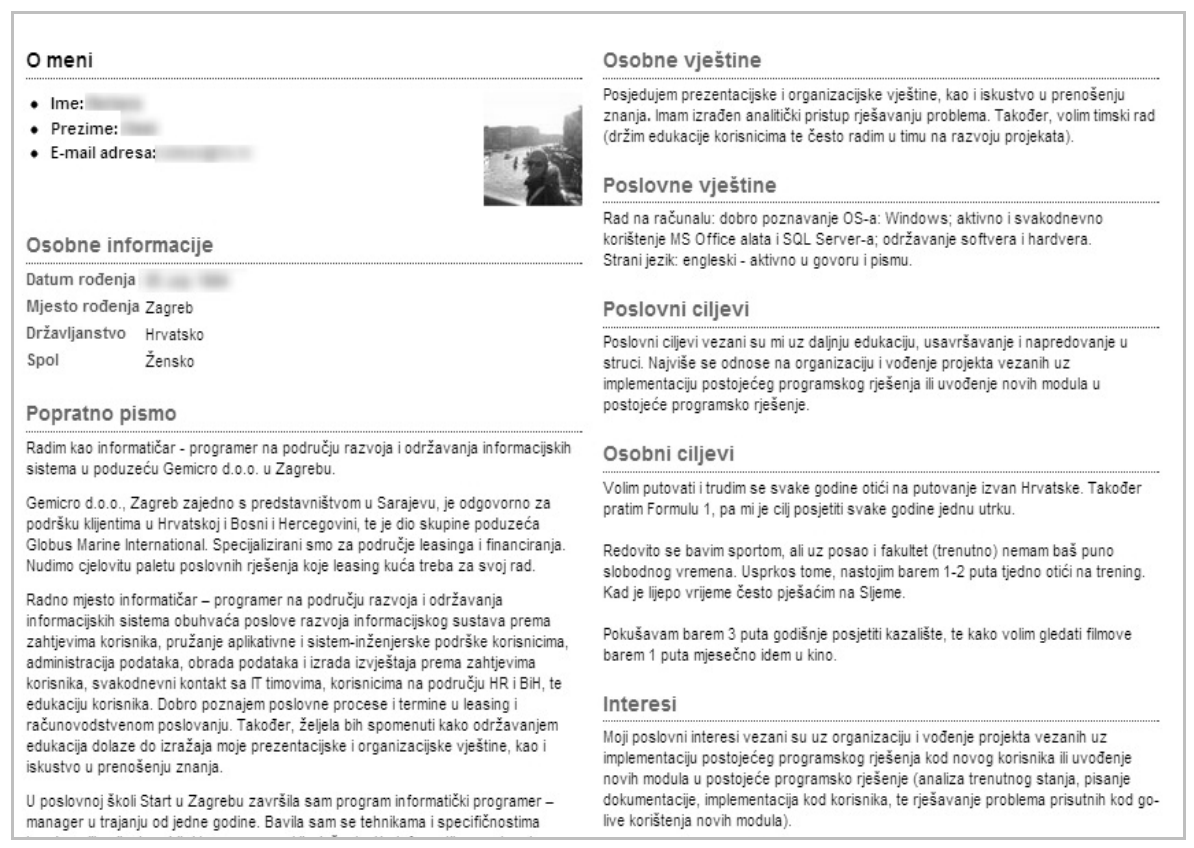

Figure 2. Example of the student's ePortfolio showcase 


\section{B. Personal Development Plan at PhD level}

The second example is focused on postgraduate students. At the Faculty of Organization and Informatics, $\mathrm{PhD}$ students keep an obligatory record of their learning and scientific research within their doctoral studies in form of ePortfolio. The presentation of personal achievements with the use of ePortfolio system (based on their previous undergraduate activities and current graduate experience) seemed suitable to support these kinds of selfreflective activities at $\mathrm{PhD}$ level as well. The other idea for using the ePortfolio system was to encourage postgraduate students in planning a balanced development of their careers as scientific researchers and experts.

Personal Development Planning (PDP) is "a structured and supported process undertaken by an individual to reflect upon their own learning, performance and/or achievement and to plan for their personal, educational and career development" (QAA, 2009). In general, PDP is: (a) concerned with learning in holistic sense; (b) based on reflection and planning skills; (c) something that individual does with guidance and support; (d) intended to improve capacity of individuals; (e) a process that involves self-reflection, as well as planning and monitoring progress towards the achievement of personal goals (QAA, 2009). Moreover, the Researcher Development Framework (Vitae RDF, n.d.) was used as a basis to align $\mathrm{PhD}$ requirements with PDP. To better support this initiative a PDP handbook for PhD students was prepared. This handbook provides students with the structure and stepby-step explanation on how to organize their Personal Development Plan in ePortfolio. Doctoral students can use such a Personal Development Plan for self-presentation to their teachers, supervisors, colleagues and other stakeholders such as potential employers, project managers, etc., as well as to help supervisors to more easily communicate with their $\mathrm{PhD}$ candidates. An example of an ePortfolio Personal Development Plan at the $\mathrm{PhD}$ level is shown in figure 4.

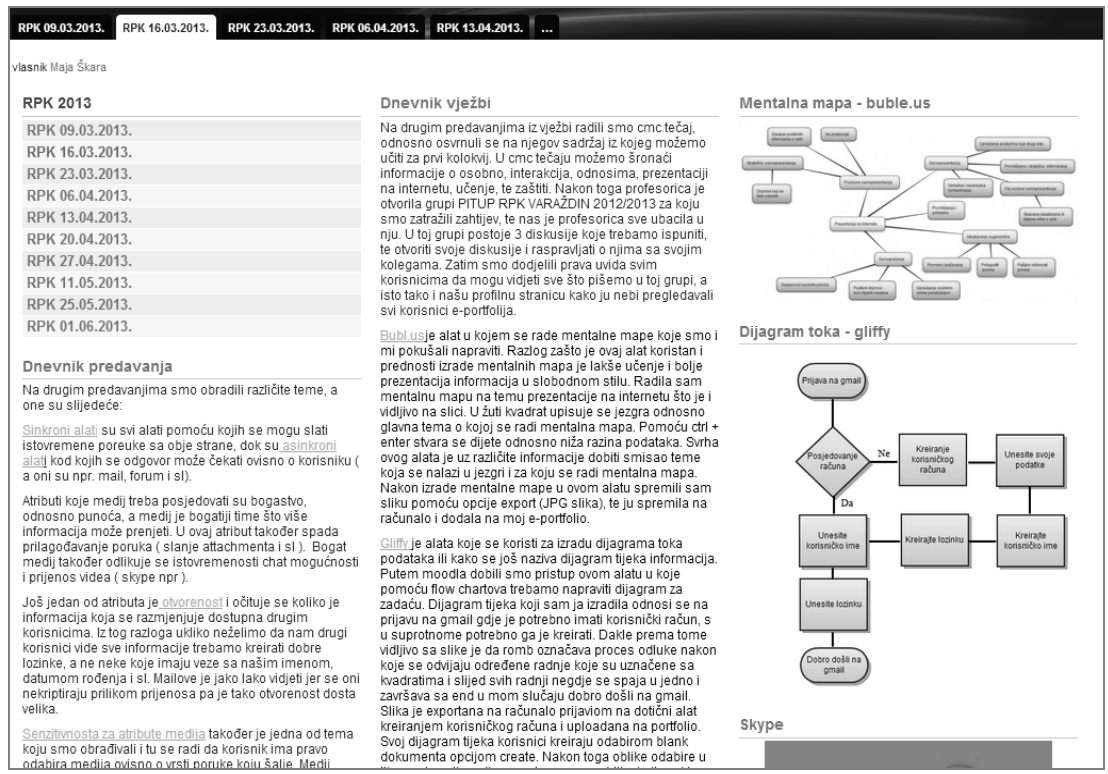

Figure 3. Example of ePortfolio learning diary

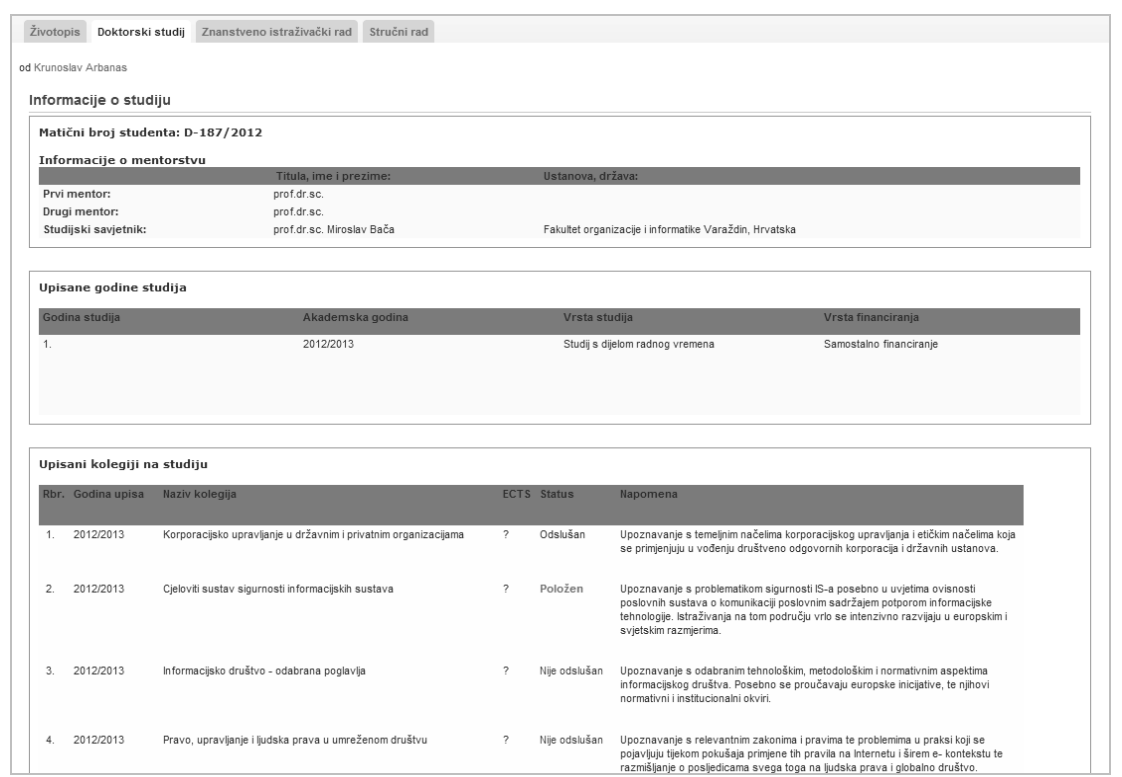

Figure 4. Example of ePortfolio Personal Development Plan at PhD level 
The Personal Development Plan of PhD students encompasses the following elements: (1) planned and enrolled courses and estimated date by which candidates plan to pass them; (2) estimated date by which candidates plan to approach the qualification exam (that needs to be passed before the submission of the thesis topic proposal); (3) estimated date by which candidates plan to submit their thesis topic proposal; (4) estimated date by which candidates plan to implement the research plan; (5) list of skills they need to gain to successfully finish their $\mathrm{PhD}$ studies and the way in which they plan to gain them; (6) fields of interest etc. A candidate's Personal Development Plan should also include other elements like scientific projects that they are part of; list of their publications; list of workshops and conferences they plan to attend, list of references they have read regarding their thesis and a list of journals they follow, among others. A Personal Development Plan thus captures and analyzes candidates' achievements, helps them to set their short-, medium- and long-term goals, conceive and plan activities and monitor their implementation. This particular use of ePortfolio at the Faculty of Organization and Informatics is still in its early stage but its implementation has so far generally yielded positive and promising feedback.

\section{Career Development Plan}

The third example of ePortfolio use in this paper is focused on employee (staff) portfolio, where all teaching assistants and young researchers employed at the Faculty of Organization and Informatics, need to create their Career Development Plan (CDP) in ePortfolio. Increasing requirements for academic employment make career management even more vital in improving one's chances for future employability. A Career Development Plan is similar to Personal Development Plan but more professionoriented. As a background for CDP, two different frameworks were used: (1) Researcher Development Framework (Vitae RDF, n.d.), and (2) Research Skill Development for curriculum design and assessment (Adelaide et al., n.d.). At the Faculty of Organization and Informatics, CDP is divided into four main categories: (1) scientific research; (2) teaching; (3) professional work; and (4) social activity

Scientific research encompasses specific knowledge and skills necessary to plan and perform scientific research (e.g. scientific methods) as well to document the results of their scientific research (participation in research projects and scientific publications: books, papers, presentations etc.). Furthermore, within this module it is necessary to identify three types of academic employees' goals: (1) goals for development of specific and generic research skills; (2) goals for conducting their own research; and (3) publishing goals. The specified goals can be divided into short-term (implementation deadline of up to 6 months), medium-term (implementation deadline of up to 3 years) and long-term goals (implementation deadline over 3 years). For each goal it is necessary to provide appropriate activities and resources required to fulfill them.

The teaching module incorporates specific knowledge and skills necessary for successful preparation and implementation of teaching within the courses that teaching assistants and young researchers are involved in. Previous results of teaching are shown through: (1) records of con- ducted classes (titles, role and teaching hours); (2) records of mentoring and work with students; (3) type and number of instructional materials and textbooks produced. The results of employees' knowledge and skills acquisition are shown in sections containing an overview of knowledge and teaching methods as well as plans for improving teaching competences.

The professional work module of the CDP focuses on employees' specific knowledge and skills gained for the implementation of research projects into industry and real life (including certificates), with a showcase of their experience in participating in professional projects and professional publications. In this section individual professional goals also need to be defined along with activities and required resources.

Social activity is the last structured section of the CDP. It is a record of the employees' contribution to initiating positive change and social development of local and global reach. It includes employees' actions ranging from civic associations, political organizations, social institutions and bodies of local and regional government, volunteering, among others. In this section it is also necessary to specify memberships and functions in various organizations, functions in state and local or regional authorities, memberships in working groups and advisory bodies as well as other types of activities that contribute to overall social development.

At the Faculty of Organization and Informatics, the management board has been implementing CDP with the aim of encouraging balanced planning and career development of their employees. In addition, it also allows the management simplified monitoring and reports preparation required for scientific and academic advancement of their employees.

\section{CONCLUSION}

There is no doubt that ePortfolio implementation entails transformations of the learning system in terms of how and where people learn, who the learners are and who the beneficiaries are. Some authors argue that educational uses of ePortfolio comprise both a technology and a pedagogy [8], which has also proved true in the case of ePortfolio uses in our paper. In our experience several pedagogical outcomes of ePortfolio implementation at the undergraduate and graduate level have been identified: encouraging learners' reflection about the process and outcomes of learning, supporting better insight and evaluation of learners' progress during study, stimulating deeper learning of course content and facilitating online collaboration and peer-to-peer learning, among others. Further, the use of ePortfolio helped learners to plan and manage their development direction, career choice and develop their identities. Numerous benefits of ePortfolio for various stakeholders including teachers, students, management boards, administrative/support departments and potential employers were also revealed. However, motivating learners to recognize and extend the value of ePortfolio outside the borders of formal education to support their growth personally and professionally can prove to be a challenge. Despite its evident potential in creating PDP and CDP, such uses of ePortfolio yet need to be popularized among $\mathrm{PhD}$ students and academic employees. 


\begin{tabular}{|c|c|c|c|c|c|c|c|c|c|}
\hline \multirow{2}{*}{$\begin{array}{l}\text { Životopis } \\
\text { od Ana Cori }\end{array}$} & \multicolumn{2}{|c|}{ Znanstveno-istraživački rad } & Nastavne aktivnosti & sti Stručni rad 0 & Ostale aktivnosti & \multicolumn{4}{|l|}{$\ldots$} \\
\hline & & & & & & & & & \\
\hline \multicolumn{6}{|c|}{ Informacije o doktorskom studiju } & \multicolumn{4}{|c|}{ Znanstveni projekti } \\
\hline \multirow{2}{*}{\multicolumn{2}{|c|}{$\begin{array}{l}\text { Naziv doktorskog } \\
\text { studija }\end{array}$}} & \multirow{2}{*}{\multicolumn{2}{|c|}{ Znanstveno polje }} & \multirow{2}{*}{$\begin{array}{l}\text { Indtitucija nositelj } \\
\text { studija }\end{array}$} & \multirow{2}{*}{$\begin{array}{l}\text { Datum } \\
\text { upisa }\end{array}$} & \multirow{3}{*}{$\begin{array}{l}\text { Početak Kraj } \\
2009\end{array}$} & Naziv projekta (šifra projekta) & \multicolumn{2}{|l|}{ Uloga na projektu } \\
\hline & & & & & & & \multirow{2}{*}{$\begin{array}{l}\text { Komunikacijske vještine i tehnologije } \\
\text { u komunikaciji Internetom i e- } \\
\text { obrazovanju (016-0000000-1746) }\end{array}$} & \multirow{2}{*}{\multicolumn{2}{|c|}{$\begin{array}{l}\text { Znanstveni novak } \\
\text { - sudjelovanje u organiziranju } \\
\text { radionica } \\
\text { - sudjelovanje u provođenju } \\
\text { istrażivanja } \\
\text { - sudjelovanje u pisanju radova }\end{array}$}} \\
\hline \multicolumn{2}{|c|}{$\begin{array}{l}\text { Doktorski studij } \\
\text { Informasijske } \\
\text { znanosti }\end{array}$} & \multicolumn{2}{|c|}{$\begin{array}{l}\text { Druśtvenih znanosti iz } \\
\text { znanstvenog polja informacijskih } \\
\text { znanosti }\end{array}$} & $\begin{array}{l}\text { Fakultet } \\
\text { organizacije i } \\
\text { infromatike }\end{array}$ & & & & & \\
\hline \multicolumn{6}{|c|}{ Upisani kolegiji na doktorskom studiju } & \multicolumn{4}{|c|}{ Znanstveno-istraživački rad } \\
\hline Rbr. & Godina upisa & \multicolumn{3}{|c|}{ Naziv kolegija } & Status & \multirow{2}{*}{\multicolumn{2}{|c|}{$\frac{\text { Datum završetka }}{28 \text { September } 2012}$}} & Naslov & Završeno \\
\hline 1. & $2009 / 2010$ & \multicolumn{3}{|c|}{ Informacijsko društvo - odabrana poglavija } & Položeno & & & $\begin{array}{l}\text { Mobilnost ERASMUS Hogeschool van } \\
\text { Amsterdam }\end{array}$ & $\checkmark$ \\
\hline 2. & $2009 / 2010$ & \multicolumn{3}{|c|}{$\begin{array}{l}\text { Korporacijsko upravljanje u državnim i privatnim } \\
\text { organizacijama }\end{array}$} & Polożeno & \multicolumn{2}{|l|}{09 November 2012} & $\begin{array}{l}\text { rraining SchOol: } \\
\text { for Human-Computer } \\
\text { FEM) }\end{array}$ & $\checkmark$ \\
\hline 3. & $2009 / 2010$ & Odabrana pogla & IVlja elektroničkog po & oslovanja & Položeno & 01 March 2013 & Priprema Clanka za & tásopis & \\
\hline 4. & $2009 / 2010$ & $\begin{array}{l}\text { Odabrana pogla } \\
\text { tehnologijom }\end{array}$ & ivlja iz upravljanja inf & formacijskom & Položeno & 01 May 2013 & $\begin{array}{l}\text { Konferencija CECII } \\
\text { studentom) }\end{array}$ & IS 2013 (rad sa & $\checkmark$ \\
\hline 5. & $\begin{array}{l}2009 / 2010 \\
2010 / 2011\end{array}$ & Organizacijska & kultura & & Polożeno & 15 May 2013 & $\begin{array}{l}\text { Sudjelovanje na me } \\
\text { seminaru IDS Dubrc }\end{array}$ & $\begin{array}{l}\text { edunarodnom doktorskom } \\
\text { rovnik }\end{array}$ & 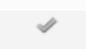 \\
\hline 7. & $2010 / 2011$ & $\begin{array}{l}\text { Odabrana pogla } \\
\text { mentoriranja u }\end{array}$ & $\begin{array}{l}\text { ivja iz instrukcijskog } \\
\text {-obrazovanju }\end{array}$ & dizajna i & Polożeno & & 5 obaveze & & \\
\hline 8. & 2010/2011 & Pravo, upravlja & nje i judska prava u & umreženom društvu & Položeno & Znanstveno ist & traživačke vještine & & \\
\hline $\begin{array}{l}9 . \\
10\end{array}$ & $\begin{array}{l}2010 / 2011 \\
2012 / 2013\end{array}$ & $\begin{array}{l}\text { Stanje i razvoj } \\
\text { Kvalifikacijski }\end{array}$ & $\begin{array}{l}\text { ERP sustava } \\
\text { doktorski ispit }\end{array}$ & & $\begin{array}{l}\text { Polożeno } \\
\text { U pripremi }\end{array}$ & - Pisanje znan & stvenih radova & & \\
\hline Plan o & aveza - Doktc & torski studij & & & & - Inferencijalr & na statistika & & \\
\hline Datum & ivršetka & & Naslov & & Završeno & - Metode anali & lize SAW i TOPSIS & & \\
\hline 01 Marc & 2011 & & Stanje i razvoj ERP & sustava & $\checkmark$ & & & & \\
\hline $29 \mathrm{Febr}$ & iry 2012 & & Metamodeliranje & & $\checkmark$ & instveno-ist & traživački rad - Znanstvene publika & aciie & \\
\hline 10 July & & & $\begin{array}{l}\text { Pravo. upravljanje } \\
\text { umreżenom društv. }\end{array}$ & $\underset{u}{i}$ l judska prava u & $\checkmark$ & anstveno-lst & trazivacki rad - Znanstvene pubika & & \\
\hline 01 June & 2013 & & $\begin{array}{l}\text { Pripremati prijavu z } \\
\text { ispit }\end{array}$ & za kvalifikacijski doktors & rski & Poplavia u knir & stvenin rezulta & & \\
\hline 01 Sept & mber 2013 & & $\begin{array}{l}\text { Pripremati prijavu z } \\
\text { ispit II. put }\end{array}$ & za kvalifikacijski doktors & rski & $\begin{array}{l}\text { Znanstveni rad } \\
\text { Znanstveni rad }\end{array}$ & $\begin{array}{l}\text { dovi u drugim časopisima (3) } \\
\text { dovi u zbornicima skupova s medunar.rec. (10) }\end{array}$ & & \\
\hline 01 Sept & mber 2013 & & Izraditi prijedlog nac & crta istraživanja & & & & & \\
\hline 01 Sept & mber 2013 & & Izraditi pregledni ra: & Id istraživanja & & & & & \\
\hline 01 Sept & mber 2013 & & Priprema pregleda & literature. & & Poglavlja u knjo & & & \\
\hline 30 Sept. & mber 2013 & & Pristupiti kvalifikac & cijskom doktorskom ispi & & & & & \\
\hline 30 octo & er 2013 & & $\begin{array}{l}\text { Pokretanje postupk } \\
\text { doktorskog rada }\end{array}$ & ca prihvaćanja teme & & $\begin{array}{l}\text { Evaluation of } \\
\text { Pedagogy an } \\
\text { Leszek; Diks. }\end{array}$ & $\begin{array}{l}\text { of Web } 2.0 \text { Tools in the e-Learning, Context: } \\
\text { nd Usability // University Information System } \\
\text {, Krzysztof ; Madey. Jan (ur.). Varśava : Difin }\end{array}$ & $\begin{array}{l}\text { Case Studies Related to } \\
\text { ns - Selected Problems / R } \\
\text { n SA, 2010. Str. 259-277. }\end{array}$ & Ludak. \\
\hline
\end{tabular}

Figure 5. Example of employee ePortfolio Career Development Plan

\section{REFERENCES}

[1] B. Barrett, "E-Portfolio Programs as Strategic Tools for Implementation and Evaluation," Rev. Bus. Res., vol. 10, no. 2, pp. 5662, Mar. 2010.

[2] J. Van Merriënboer, P. A. Kirschner, F. Paas, P. Sloep, and M. Caniëls, "Towards an Integrated Approach for Research on Lifelong Learning," Jun. 2009.

[3] Y. Gulbahar and H. Tinmaz, "Implementing Project-Based Learning and E-Portfolio Assessment in an Undergraduate Course," $J$. Res. Technol. Educ., vol. 38, no. 3, pp. 309-327, 2006. http://dx.doi.org/10.1080/15391523.2006.10782462

[4] P. Hall, A. Byszewski, S. Sutherland, and E. J. Stodel, "Developing a Sustainable Electronic Portfolio (ePortfolio) Program That Fosters Reflective Practice and Incorporates CanMEDS Competencies Into the Undergraduate Medical Curriculum," Acad. Med., vol. 87, no. 6, pp. 744-751, Jun. 2012. http://dx.doi.org/10.1097/ ACM.0b013e318253dacd

[5] A. Garthwait and J. Verrill, "E-Portfolios: Documenting Student Progress.," Sci. Child., vol. 40, no. 8, pp. 22-27, 2003.

[6] A. Coric, I. Balaban, and G. Bubas, "Case studies of assessment ePortfolios," in 2011 14th International Conference on Interactive Collaborative Learning (ICL), 2011, pp. 89-94.

[7] N. B. Milman, "Web-Based Digital Teaching Portfolios: Fostering Reflection and Technology Competence in Preservice Teacher Education Students," J. Technol. Teach. Educ., vol. 13, no. 3, pp. 373-396, Jul. 2005.

[8] P. Gerbic, L. Lewis, and M. Northover, "Student perspectives of eportfolios: A longitudinal study of growth and development." Proceedings ascilite Auckland, 2009.

[9] C.-C. Chang, K.-H. Tseng, C. Liang, and T.-Y. Chen, "Using eportfolios to facilitate university students' knowledge management performance: E-portfolio vs. non-portfolio," Comput. Educ., vol. 69, pp. 216-224, Nov. 2013. http://dx.doi.org/10.1016/j.compedu. 2013.07.017

[10] Chin-Hung Lin, Shu-Ching Yang, and Chin-Chi Lai, "Support as a Mediator of the Impact of Cognitive Load on Students' EPortfolio Learning Outcomes," Soc. Behav. Personal. Int. J., vol. 41, no. 1, pp. 17-30, Jan. 2013. http://dx.doi.org/10.2224/ sbp.2013.41.1.17

[11] Mu-Yen Chen, F. m.-T. Chang, Chia-Chen Chen, Mu-Jung Huang, and Jing-Wen Chen, "Why do Individuals Use eportfolios?," Educ. Technol. Soc., vol. 15, no. 4, pp. 114-125, Oct. 2012.

[12] J.-Y. Tzeng and S.-H. Chen, "College students' intentions to use e-portfolios: From the perspectives of career-commitment status and weblog-publication behaviours," Br. J. Educ. Technol., vol. 43, no. 1, pp. 163-176, Jan. 2012. http://dx.doi.org/10.1111/ j.1467-8535.2010.01165.x

\section{AUTHORS}

A. Coric Samardzija is junior researcher/teaching assistant and PhD student at University of Zagreb, Faculty of Organization and Informatics, Varazdin (e-mail: acoric@foi.hr).

I. Balaban is Assistant Professor at University of Zagreb, Faculty of Organization and Informatics, Varazdin. $\mathrm{He}$ is also a coordinator of Europortfolio project available at: http://www.europortfolio.org. (e-mail: ibalaban@, foi.hr).

Submitted 11 July 2014. Published as resubmitted by the authors 08 December 2014. 